\title{
Urea as a nutrient: bioavailability and role in nitrogen economy
}

Urea is known to be an end product of mammalian metabolism and has generally been considered to be of no metabolic significance. The nitrogen of urea can however be salvaged through the metabolic activity of the colonic microflora and is potentially available for further metabolic interaction and may contribute directly to the effective supply of nitrogen to the body.

By 1946 it was known that urea was produced almost exclusively in the liver through the activity of the KrebsHenseleit cycle. As an end product of mammalian metabolism it was considered to be excreted quantitatively in urine, representing the major form in which nitrogen was lost from the body. Over the next 10 years, with the use of isotopic tracers, it was demonstrated that in cats, pigs, and rats a portion of the urea produced was normally retained within the system. In 1959 it was shown that in normal man about 20 to $30 \%$ of the urea produced was retained. ${ }^{1}$ The retention followed hydrolysis, which was shown to be a product of bacterial, rather than mammalian, metabolism and could be directly attributable to the colonic microflora. ${ }^{2}$ During the 1960 s and early 1970 s the clinical implications of this phenomenon were explored in relation to the efficiency of adaptation to low protein diets, hepatic failure, and renal disease and more recently to the management of urea cycle disorders. ${ }^{3}$ In the context of animal production, the functional relevance of salvage of urea nitrogen on the overall nitrogen economy is established as important, but in clinical circles initial enthusiasm was not sustained. The clinical response to low protein diets was not as dramatic as originally anticipated and a number of potential theoretical problems related to the interpretation of tracer kinetic studies remained unresolved.

\section{Urea metabolism}

Dietary protein is the main form in which nitrogen is taken into the body and after digestion amino acids are absorbed and become a part of the body's metabolic pool. The amino acids have one of two potential fates: to be utilised for synthetic purposes and made into the body's own protein, or to be oxidised as a source of energy for the body with the amino group being made into end products, predominantly urea. ${ }^{4}$ The overall activity of the system is determined by the demand for protein synthesis which is under genetic, dietary, hormonal, and other control. The intensity of protein turnover is 10 to 15 times as great as the dietary intake of protein during infancy and consumes a large proportion of the daily requirement for energy. 56

In the normal course of events amino acids contribute to satisfying the requirements of the body for energy. In adults the oxidation of amino acids accounts for about 15 to $20 \%$ of the energy required. In the fetal lamb, by comparison, at least $40 \%$ of energy is derived from the oxidation of amino acids, and in situations of maternal nutrient deprivation this may rise to $60 \%$ of total energy. ${ }^{7}$ It is not clear why there should be such a considerable dependency in early life upon amino acid oxidation; apparently an inefficient use of amino acids. There is a stoichiometric match between amino acid oxidation and urea formation. In the unstressed fetal lamb, urea formation is around 12 to $15 \mathrm{mg}$ nitrogen/ $\mathrm{kg} /$ hour, increasing to $40 \mathrm{mg}$ nitrogen $/ \mathrm{kg} /$ hour with maternal nutrient deprivation. ${ }^{7}$ In the human neonate protein oxidation, based on the measurement of leucine kinetics, is about $9.3 \mathrm{mg}$ nitrogen $/ \mathrm{kg} /$ hour, ${ }^{8}$ similar to direct measures of urea formation on an established dietary intake, $10 \mathrm{mg}$ nitrogen $/ \mathrm{kg} /$ hour. ${ }^{9}$ Both are similar to the unstressed fetal lamb, which implies a similar rate of utilisation of amino acids as a source of energy in the newborn as in the fetus. This suggests that the oxidation of amino acid as a source of energy is a major drive for urea formation. Whereas in the fetus the large amounts of urea produced can be handled metabolically, simply by the product moving across the placenta to the maternal circulation, in the newborn the renal excretion of such large quantities of urea would require a free water clearance of considerable magnitude. Therefore, if the renal capacity is not to be overwhelmed, there is the need for a substantial portion of the urea nitrogen to be handled safely. Under usual circumstances colonic salvage is important for the handling of urea nitrogen with the nitrogen being returned to the metabolic pool. The system requires the establishment of a normal colonic flora. In fasted, young neonates without an established dietary intake urea appearance, $5.3 \mathrm{mg}$ nitrogen $/ \mathrm{kg} /$ hour, ${ }^{10}$ was similar to that in neonates on total parenteral nutrition who had never had a full dietary intake, $3.5 \mathrm{mg}$ nitrogen $/ \mathrm{kg} /$ hour. $^{11}$

The rate at which urea nitrogen is salvaged is determined by the dietary intake of protein in relation to the metabolic demand for protein synthesis and net protein accretion. For a fixed demand, salvage increases as intake falls. For a fixed intake, salvage increases as the demand increases. Therefore salvage is enhanced when the metabolic demand increases for either physiological (for example, in pregnancy or during childhood) or pathological reasons (for example, after surgery, in hypersplenism in sickle cell disease, or during catch up growth). ${ }^{412}$

\section{Dietary urea and urea salvage}

Urea is a normal constituent of milk and in the human may comprise as much as $15 \%$ of the nitrogen content. ${ }^{13}$ Human milk is relatively low in nitrogen and when account is taken of the non-protein nitrogen the level of protein intake in breast fed infants is exceptionally low $\left(0.7 \mathrm{~g} / 100 \mathrm{ml}^{14}\right)$ relative to their rate of growth and overall metabolic demand. Under these circumstances the metabolic fate of the nonprotein nitrogen components of the milk become important. In a number of studies a single dose of isotopically labelled urea has been given orally and the recovery of label in urine measured. In all studies a proportion of label was retained, varying from 6 to $60 \%$, implying that about $40 \%$ or oral urea is retained, ${ }^{15-18}$ presumably through hydrolysis and salvage. When the endogenous production of urea is measured directly even higher rates of salvage have been obtained, up to $80 \%$ of the rate of urea production. ${ }^{911}$ Although none of the infants in the latter studies could be considered normal, similar data have been obtained recently in normal breast fed infants (H A Steinbrecher and A A Jackson, unpublished observations). Therefore high rates of urea production and salvage appear to be a normal feature of early infancy.

\section{Fate of urea nitrogen}

The fate of the urea nitrogen remains an unresolved issue. The more traditional concept presumes that ammonia derived from urea hydrolysis passes to the liver where it is either fixed as 'non-essential amino acids' or returned to urea formation. The demands for non-essential amino 
acids during growth and development is considerable and may be satisfied in part through a mechanism of this kind. ${ }^{1214}$ However, there is also evidence that nitrogen, derived from urea, is fixed by the colonic bacteria into amino acids and protein and is thereby potentially available to the host. The implication of this would be that amino acids (both non-essential and essential) derived from bacterial synthesis are made available in functionally significant amounts and contribute to satisfying the amino acid requirements of the host. There are human ${ }^{19-21}$ and animal $^{22} 23$ data in favour of this suggestion, but they are not considered sufficiently strong to carry general opinion at the present time. The resolution of this point is important for establishing the adequacy of diets to satisfy the requirements for nitrogen, amino acid, and proteins. The possibilities are not mutually exclusive, and either allows for a significant role of urea salvage in maintaining normal nitrogen metabolism.

\section{Conclusions}

It is now clear that an understanding of urea metabolism is of importance for appreciating two aspects of protein/energy interactions during early life. Firstly the utilisation of amino acids as a major source of energy is inevitably associated with the formation of large amounts of urea. Secondly, the nitrogen derived from urea hydrolysis might contribute directly to the formation of amino acids, needed to satisfy the demands for normal growth and development. It remains for future work to determine the extent to which this complex interaction functions to modulate the pattern of amino acids available to the infant. When this information is available it will be possible to determine the extent to which the functional role of the colon is critical for normal health, ${ }^{24}$ the particular effect of gastrointestinal disorders such as diarrhoeal disease, and the implications for the design of infant formulas. ${ }^{25}$

Department of Human Nutrition,

A A JACKSON

University of Southampton,

Bassett Crescent East.

Southampton SO9 $3 T U$
1 Walser M, Bodenlos LJ. Urea metabolism in man. $f$ Clin Invest 1959; 38: 1617-26.

2 Levenson SM, Crowley LV, Horowitz RE, Malm OJ. The metabolism of carbon labelled urea in the germ free rat. $\mathcal{F}$ Biol Chem 1959; 234: 2061-2.

3 Richards P. Nutritional potential of urea recycling in man. Am $\mathcal{F}$ Clin Nutr 1972; 25: 615-25.

4 Jackson AA. Chronic malnutrition: protein metabolism. Proc Nutr Soc 1993; 52: $1-10$.

5 Waterlow JC. Protein turnover with special reference to man. Quarterly fournal of Experimental Physiology 1984; 69: 409-38.

6 Jackson AA. Optimizing amino acid and protein supply in the newborn. Proc Nutr Soc 1989; 48: 293-301.

7 Owens JA, Owens PC, Robinson JS. Experimental fetal growth retardation: metabolic and endocrine aspects. In: Gluckman PD, Johnston BM, Nathanielsz PW, eds. Advances in fetal physiology: reviews in honours of GC Liggins. Ithaca: Perinatology Press, 1989: 263-86.

8 Denne SC, Kalhan SC. Leucine kinetics during feeding in normal newborns. Pediatr Res 1991; 30: 23-7.

9 Wheeler RA, Jackson AA, Griffiths DM. Urea production and recycling in the neonate. $\mathcal{F}$ Pediatr Surg 1991; 26: 575-7.

10 Kalhan SC. Rates of urea synthesis in the human newborn: effect of maternal diabetes and gestational age. Pediatr Res (in press).

11 Wheeler RA, Griffiths DM, Jackson AA. Urea kinetics in neonates receiving total parenteral nutrition. Arch Dis Child 1993; 69: 24-7.

12 Jackson AA, Wootton SA. The energy requirements of growth and catch-up growth. In: Schurch B, Scrimshaw NS, eds. Activity, energy expenditure and energy requirements of infants and children. Lausanne, Switzerland: International Dietary Energy Consultative Group, Nestle Foundation, 1990: 185-214.

13 Harzer G, Franzke V, Bindels JG. Human milk non-protein nitrogen components: changing patterns of free amino acids and urea in the course of lactation. Am F Clin Nutr 1984; 40: 303-9.

14 Raiha NCR. Milk protein quantity and quality and protein requirements during development. Adv Pediatr 1989; 36: 347-68.

15 Hein W, Tiess M, Stolpe HJ, Wutzke K. Urea utilization by the intestinal flora, of infants fed milk and a formula diet, as measured with $15 \mathrm{~N}$-tracer flora, of infants fed milk and a formula diet, as measured

16 Heine W, Tiess M, Wutzke KD. $15 \mathrm{~N}$-tracer investigations of the physiological availability of urea nitrogen in mothers milk. Acta Paediatr Scand 1986; 75: 439-43.

17 Fomon SJ, Matthews DE, Bier DM, et al. Bioavailability of dietary urea nitrogen in the infant. $\mathcal{F}$ Pediatr 1987; 111: 221-4.

18 Fomon SJ, Matthews DE, Bier DM, et al. Bioavailability of dietary urea nitrogen in the breast fed infants. $\mathcal{F}$ Pediatr 1988; 113: 515-7.

19 Kies C, Fox HM. Urea as a dietary supplement for humans. Adv Exp Med Biol 1978; 105: 103-18.

20 Tanaka N, Kubo K, Shiraki K, Koishi H, Yoshimura H. A pilot study on protein metabolism in Papua New Guinea highlanders. $f \mathrm{Nutr} S \mathrm{Sci}$ Vitaminol (Tokyo) 1980; 26: 247-59.

21 Heine W, Wutzke KD, Richter I, Walther F, Plath C. Evidence for colonic absorption of protein nitrogen in infants. Acta Paediatr Scand 1987; 76: $741-4$.

22 Tanaka N. Urea utilization in protein deficient rats. Fournal of the fapanese Society of Nutrition and Food Science 1982; 35: 175-80.

23 Torrallardona D, Harris CI, Milne E, Fuller MF. Contribution of intestinal microflora to lysine requirements of non-ruminants. Proc Nutr Soc 1993; 52: $153 \mathrm{~A}$.

24 Moran BJ, Jackson AA. Function of the human colon. Br f Surg 1992; 79: 1132-7.

25 Fomon SJ. Requirements and recommended dietary intakes of protein during infancy. Pediatr Res 1991; 30: 391-5. 